\title{
A gene from Renibacterium salmoninarum encoding a product which shows homology to bacterial zinc-metalloproteases
}

\author{
Thomas H. Grayson, ${ }^{1}$ Andrew J. Evenden, ${ }^{1}$ Martyn L. Gilpin, ${ }^{1}$ \\ Keith L. Martin ${ }^{2}$ and Colin B. Munn ${ }^{1}$
}

Author for correspondence: C. B. Munn. Tel: +44 1752 232940. Fax: +44 1752232970.

1 Department of Biological Sciences, 6 Queen Anne Terrace, University of Plymouth, Plymouth PL4 8AA, UK

2 Chemical and Biological Defence Establishment, Porton Down, Salisbury, Wiltshire SP4 0JQ, UK

\begin{abstract}
A genomic library constructed from Renibacterium salmoninarum isolate MT444 DNA in the plasmid vector pBR328 was screened using Escherichia coli host strain DH1 for the expression of genes encoding putative virulence factors. A single haemolytic clone was isolated at $22^{\circ} \mathrm{C}$ and found to contain a $3.1 \mathrm{~kb}$ HindIII fragment of inserted DNA. This fragment was present in seven isolates of R. salmoninarum which were examined. Western blots of extracts from clones exhibiting haemolytic activity were performed with antisera raised against either cellular or extracellular components of $R$. salmoninarum and failed to identify any additional proteins compared to control $E$. coli containing pBR328. However, minicell analysis revealed that a polypeptide with an apparent molecular mass of $65 \mathrm{kDa}$ was associated with a haemolytic activity distinct from that previously described for $R$. salmoninarum. The nucleotide sequence of the gene encoding this product was determined and the amino acid sequence deduced. The product was 548 amino acids with a predicted molecular mass of $66757 \mathrm{Da}$ and a pl of 5.57. The deduced amino acid sequence of the gene possessed strong similarities to those of a range of secreted bacterial zinc-metalloproteases and was tentatively designated $h / y$. Neither protease nor lecithinase activities were detectable in E. coli recombinants expressing gene hly. Haemolytic activity was observed from $6^{\circ} \mathrm{C}$ to $37^{\circ} \mathrm{C}$ for erythrocytes from a number of mammalian species and also from fish. Gene hly was expressed in E. coli as a fusion protein consisting of maltose-binding protein at the $\mathrm{N}$-terminus linked to all but the first 24 amino acids, largely constituting the putative signal peptide, of the $\mathbf{N}$-terminus of Hly. The soluble fusion protein was produced and purified by affinity chromatography. Antiserum raised against the purified fusion protein was used to probe Western blots of cell lysates and extracellular products from seven isolates of $R$. salmoninarum cultured under conditions of iron-sufficiency or iron-restriction. The results indicate that the availability of iron modulates the expression of the hly gene.
\end{abstract}

Keywords: Renibacterium salmoninarum, bacterial kidney disease, BKD, metalloprotease, gene expression

\section{INTRODUCTION}

Renibacterium salmoninarum is the causative agent of a chronic, granulomatous infection known as bacterial

Abbreviations: BKD, bacterial kidney disease; ECP, extracellular protein; MBP, maltose-binding protein.

The EMBL accession number for the nucleotide and amino acid sequence data reported in this paper is $\mathrm{X} 76499$. kidney disease (BKD) which affects farmed and wild salmonid fish worldwide (Evelyn, 1993). BKD is a particularly difficult disease to treat; there is as yet no effective vaccine, antibiotics are often ineffective and the bacterium is transmitted vertically within the salmonid egg. R. salmoninarum is a Gram-positive, slow-growing, fastidious, intracellular pathogen which is difficult to culture in vitro and this may be the major reason why little is known about the virulence or pathogenicity of the 
organism (Evenden et al., 1993). There are as yet no defined or minimal culture media available, and cultures of the bacterium may take at least 6-8 weeks to grow and are prone to contamination (Evelyn, 1993).

Many studies of $R$. salmoninarum have concentrated on the major secretory antigen, also known as antigen $F$ (Getchell et al., 1985), haemagglutinin (Daly \& Stevenson, 1990) and p57 (Wiens \& Kaattari, 1991). This protein is the predominant cell surface and extracellular protein (ECP) of the bacterium and has been associated with hydrophobicity and virulence (Bruno, 1988, 1990). However, the characterization of other components which may be of importance to the progression of infection is required in order to provide an improved understanding of BKD. In particular, molecules which may be associated with the invasion of and survival within host cells, or which modulate the host immune response, such as haemolysins or toxins, have been identified as being of considerable importance to the progress of infections caused by other intracellular pathogens (Finlay \& Falkow, 1989). As part of a comprehensive molecular study of R. salmoninarum, previous work in our laboratory has involved the cloning and expression of a haemolytic protein from the pathogen (Evenden et al., 1990).

In this study, we present the entire nucleotide sequence of a gene encoding a second haemolytic protein from $R$. salmoninarum isolate MT444 which is distinct from that previously described. As a first step in the process of understanding the role of this molecule, a fusion protein of the enzyme has been produced to provide a reliable source for further studies which will not depend upon in vitro cultures of the organism. This report describes the construction of the gene fusion and the production of antiserum to the purified fusion protein.

\section{METHODS}

Bacterial strains and plasmids. R. salmoninarum isolates MT414, MT417, MT420, MT425, MT444, MT452, 910019 and the type strain ATCC 33209 (Table 1) have been previously described (Grayson, 1993). Yersinia ruckeri strain 12/6 and Aeromonas salmonicida strain CM30 were obtained from Dr C. J. Rodgers, Fish Disease Laboratory, Ministry of Agriculture, Food and Fisheries, Weymouth, UK. Escherichia coli strains DH1 [rec A1 end $A 1$ gyr $A 96$ thi-1 bsdR $17\left(\mathrm{r}_{\mathrm{k}}^{-} \mathrm{m}_{\mathrm{k}}^{+}\right)$supE44 relA1] and XL1-Blue $\left[\operatorname{rec} A 1\right.$ end $A 1$ gyr $A 96$ thi-1 hsdR 17 sup E44 rel $A 1$ lac $\left(\mathrm{F}^{\prime}\right.$ pro $A B$ lac $I^{\mathrm{q}} \mathrm{Z} \Delta \mathrm{M} 15 \operatorname{Tn} 10\left[\right.$ tet $\left.\left.\left.^{r}\right]\right)\right]$ were used as hosts for plasmid vectors. Minicell analysis of plasmid-encoded polypeptides was performed with strain DS410 (lac rpsL $\min A \min B$ ). In some cases, strains Y1089 $\left[\Delta(\right.$ lac $) U 169$ pro $A^{+} \Delta($ lon $)$ ? araD139 str $A$

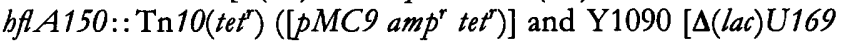

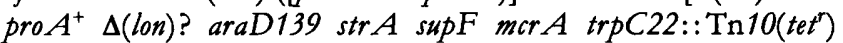
$\left(p M C 9 a m p^{r}\right.$ tet $\left.\left.t^{r}\right)\right]$ were used. The plasmid vectors pBR328, pUC18, pMAL-p and pMAL-c have been described previously (Guan et al., 1987; Maina et al., 1988). Restriction analyses and plasmid constructions were performed according to standard techniques (Maniatis et al., 1982).

Media and reagents. $R$. salmoninarum was cultured in MuellerHinton medium supplemented with $0 \cdot 1 \%$ L-cysteine hydro- chloride (MHCB) at $15^{\circ} \mathrm{C}$ and the availability of iron was restricted in cultures of $R$. salmoninarum by the addition of $200 \mu \mathrm{M}$ ethylenediamine di(o-hydroxyphenylacetic acid) (EDDHA) previously shown to be sub-inhibitory (Grayson, 1993). E. coli strains were grown in Luria-Bertani (LB) medium at either $22{ }^{\circ} \mathrm{C}$ or $37^{\circ} \mathrm{C}$ unless otherwise stated, and $0.2 \%$ glucose was added when required. For screening clones, colonies on LB agar $(1.5 \%$, w/v) plates were overlaid with $0.75 \%$ agarose containing either $1 \%(\mathrm{w} / \mathrm{v})$ casein, $0.1 \%(\mathrm{w} / \mathrm{v})$ gelatin or $20 \%(\mathrm{v} / \mathrm{v})$ fresh, washed erythrocytes of rabbit, sheep, horse, rat, mouse and rainbow trout, and compared with $E$. coli $\mathrm{DH} 1$ containing $\mathrm{pBR} 328$. Duplicate plates were incubated at $6{ }^{\circ} \mathrm{C}, 15^{\circ} \mathrm{C}, 20^{\circ} \mathrm{C}, 25^{\circ} \mathrm{C}, 30^{\circ} \mathrm{C}$ and $37^{\circ} \mathrm{C}$ for up to $4 \mathrm{~d}$ and compared at regular intervals with control plates. Brain heart infusion broth (Difco) supplemented with thiamin $\left(0.5 \mu \mathrm{g} \mathrm{ml}^{-1}\right)$ was used for minicell analysis. Antibiotics were used at the following final concentrations: $100 \mu \mathrm{g}$ ampicillin $\mathrm{ml}^{-1} ; 25 \mu \mathrm{g}$ chloramphenicol $\mathrm{ml}^{-1} ; 15 \mu \mathrm{g}$ tetracycline hydrochloride $\mathrm{ml}^{-1}$. Restriction endonucleases and ligase were purchased from Northumbria Biologicals and were used according to the manufacturer's instructions. All other chemicals and reagents were purchased from either Sigma or $\mathrm{BDH}$.

SDSPAGE and Western blotting. SDS-PAGE was performed as described by Laemmli (1970). Electrophoretic transfer of proteins to nitrocellulose was performed as described by Towbin et al. (1979). Wistar rats were immunized subcutaneously with $100 \mu \mathrm{g}$ maltose-binding protein (MBP)-Hly fusion protein emulsified in Freund's complete adjuvant, and then boosted 3 weeks later with $100 \mu \mathrm{g}$ protein emulsified in Freund's incomplete adjuvant. The rats were bled 3 weeks after the last injection. Control sera were gathered prior to immunization. Rabbit antiserum to MBP was obtained from New England Biolabs. Western blots were probed with primary antibodies and specific binding was detected by immunoperoxidase staining of horseradish-peroxidase-labelled swine anti-rabbit immunoglobulins or rabbit anti-rat IgG (Dako). Preparation of $R$. salmoninarum cell lysates and extracellular products for use in immunoblot analyses has been described previously (Grayson, 1993).

Minicell analysis. Minicell analysis was performed as described by Dougan \& Kehoe (1984). Plasmid-encoded polypeptides were specifically radiolabelled by adding $20 \mu \mathrm{Ci}(740 \mathrm{kBq})$ Tran ${ }^{35}$ S-label methionine and cysteine (ICN Flow) to a suspension of purified minicells and incubating for $30 \mathrm{~min}$. The labelled minicells were harvested, separated by SDS-PAGE, and their proteins electrophoretically transferred to nitrocellulose prior to staining the blots for total protein using colloidal gold (Aurodye; Janssen Biotech) and subjecting them to autoradiography using Kodak X-OMAT film.

Southern blot hybridization. Bacterial genomic DNA was isolated according to standard methods (Maniatis et al., 1982). Total genomic DNA was cleaved with HindIII endonuclease and the fragments produced were separated by electrophoresis at $50 \mathrm{~V}$ on a $0.75 \%$ agarose gel. The DNA was transferred to nitrocellulose filters (Southern, 1975) and probed for a specific complementary sequence using a DNA probe which had been labelled using a non-radioactive DNA labelling and detection kit according to the manufacturer's instructions (Boehringer Mannheim). Filters were prehybridized at $68^{\circ} \mathrm{C}$ for $2 \mathrm{~h}$, hybridized with $0.5 \mu \mathrm{g}$ digoxigenin-labelled probe at $68^{\circ} \mathrm{C}$ for $24 \mathrm{~h}$, washed and dried. The presence of the probe was detected with anti-digoxigenin phosphatase conjugated antiserum and visualized by enzyme-substrate colour reaction. 
Table 1. Source and origin of $R$. salmoninarum isolates used in this study

All isolates were provided by Dr D. W. Bruno, SOAFD Marine Laboratory, Aberdeen, Scotland, UK, except isolate 910019 , which was supplied by Dr C. J. Rodgers, MAFF Fish Disease Laboratory, Weymouth, England, UK.

\begin{tabular}{|c|c|c|c|c|}
\hline Isolate & $\begin{array}{c}\text { Other } \\
\text { isolate } \\
\text { numbers }\end{array}$ & $\begin{array}{l}\text { Hydrophobicity/ } \\
\text { autoagglutination }\end{array}$ & Fish source & Origin \\
\hline $\begin{array}{r}\text { ATCC } \\
33209\end{array}$ & MT 251 & + & $\begin{array}{c}\text { Oncorbyncbus } \\
\text { tshawytscba }\end{array}$ & USA \\
\hline MT 414 & MT 239 & - & Salmo salar & Scotland \\
\hline MT 417 & MT 241 & - & $\begin{array}{l}\text { Oncorbyncbus } \\
\text { kisutch }\end{array}$ & Scotland \\
\hline MT 420 & & + & Salmo salar & Scotland \\
\hline MT 425 & & + & $\begin{array}{l}\text { Oncorbynchus } \\
\text { mykiss }\end{array}$ & Scotland \\
\hline MT 452 & $222 / 88$ & - & $\begin{array}{l}\text { Oncorbyncbus } \\
\text { mykiss }\end{array}$ & Scotland \\
\hline 910019 & & + & $\begin{array}{l}\text { Oncorbyncbus } \\
\text { mykiss }\end{array}$ & England \\
\hline
\end{tabular}

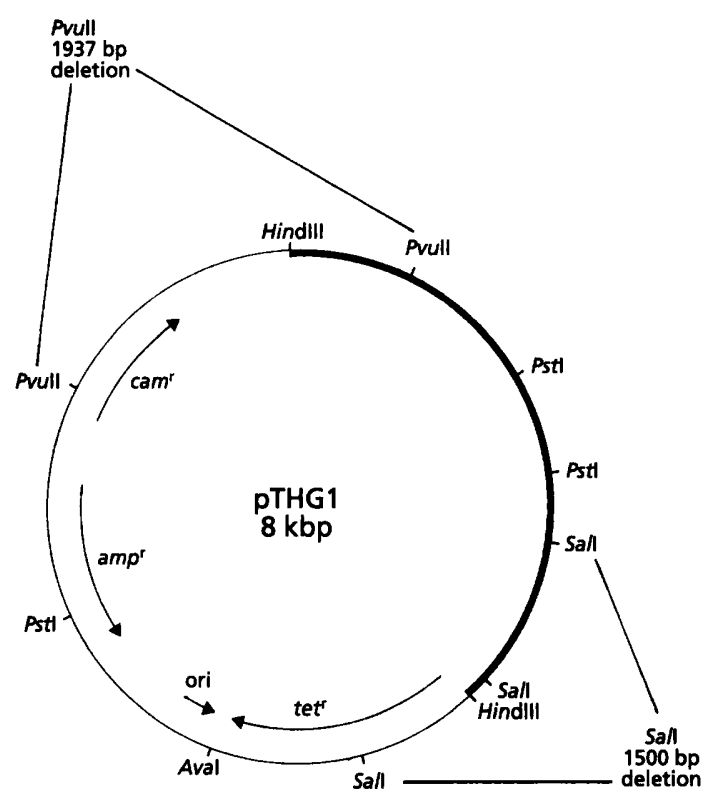

Fig. 1. Restriction map of PTHG1 DNA deduced from single enzyme digests. The $3.1 \mathrm{~kb}$ insert of $R$. salmoninarum DNA is represented by the heavy line. Also indicated are the Sall deletion and the Pvull deletion which were used in the minicell analysis of PTHG1 encoded proteins. ori, origin of replication; $\mathrm{cam}^{r}$, gene encoding chloramphenicol resistance; $a m p^{r}$, gene encoding ampicillin resistance; tet $t^{\prime}$, gene encoding tetracycline resistance.

Nucleotide sequencing. From the restriction map of pTHG1 (Fig. 1) it was decided to subclone the following fragments for sequencing: (i) HindIII-PvuII $\sim 623 \mathrm{bp}$, (ii) PvuII-PstI $727 \mathrm{bp}$ and (iii) Pst I-Pst $\sim 520 \mathrm{bp}$. The DNA sequence of the cloned $\mathrm{R}$. salmoninarum DNA was determined from double- stranded plasmid templates by dideoxy-chain termination using the Sequenase Version 2.0 kit (United States Biochemical). Double-stranded templates were denatured and the sequencing reactions were carried out according to the manufacturer's instructions. Using pUC18 primers, sequencing reactions were prepared from subclones consisting of vector $\mathrm{pUC18}$ containing fragments of R. salmoninarum DNA. Oligonucleotide forward and reverse primers were purchased from Promega; $\left[{ }^{35} \mathrm{~S}\right] \mathrm{dATP} \alpha \mathrm{S}\left[>1000 \mathrm{Cimmol}^{-1} \quad\left(37000 \mathrm{GBq} \mathrm{mmol}^{-1}\right)\right]$ was purchased from Amersham. The labelled reaction mixtures were separated under denaturing conditions by electrophoresis on either $6 \%(\mathrm{w} / \mathrm{v})$ or $4 \%(\mathrm{w} / \mathrm{v})$ polyacrylamide gels of $55 \mathrm{~cm}$ in length (Macrophor 2010, LKB), the gels dried and subjected to autoradiography. Both DNA strands of each fragment were completely sequenced, with a minimum of four forward and four reverse reactions (using both dGTP and dITP) for any given region.

Nucleotide and amino acid sequence analysis. Analyses of the nucleotide and deduced amino acid sequence were performed on DNAStar software using the PROSCAN and AALIGN programs. The best 200 scores of identity were obtained and the top 30 of these, as well as a variety of other selections, were further compared by pairwise and multiple amino acid sequence alignments with the translated $R$. salmoninarum protein sequence. Multiple sequence alignments and comparisons were carried out with the Clustal algorithm within the MEGALIGN program of DNAStar. The percentage identity of matches was scored using a gap penalty of 3 , deletion penalty of 6 and a standard probability of acceptable mutation. The prediction of $\alpha$-helix, $\beta$-sheet, turn and coil regions (Chou-Fasman, Garnier-Robson algorithms), hydrophilicity (Hopp-Woods algorithm), Eisenberg correlation of amphipathy with secondary structure, Karplus-Schulz chain flexibility, surface probability profile (Emini algorithm), and Jameson-Wolf antigenic index were also calculated.

Identification and purification of the fusion protein. A $1.7 \mathrm{kbp}$ EbeI fragment was excised from the bly gene and ligated in-frame to the StuI site of plasmids pMAL-c and pMAL-p. 
Fusion proteins were purified according to the instructions provided by New England Biolabs. Briefly, cultures of E. coli XL1-Blue containing the fusion plasmid were grown at either $22^{\circ} \mathrm{C}$ or $37^{\circ} \mathrm{C}$ to an $\mathrm{OD}_{600} \sim 0.5$. A sample of cells was removed; to the remaining culture $2 \mathrm{mM}$ IPTG and samples was added to induce expression and samples removed after 1, 2, 3 and $4 \mathrm{~h}$. All of the following steps were carried out either on ice or at $4{ }^{\circ} \mathrm{C}$ to minimize protein degradation. For affinity purification, cultures were induced for $2 \mathrm{~h}$ prior to harvesting the cells. These were resuspended in $20 \mathrm{mM}$ Tris $/ \mathrm{HCl}, 200 \mathrm{mM}$ $\mathrm{NaCl}, 1 \mathrm{mM}$ EDTA, $1 \mathrm{mM} \mathrm{NaN}, 1 \mathrm{mM}$ PMSF, $\mathrm{pH} 7 \cdot 4$. The sample was frozen overnight at $-20^{\circ} \mathrm{C}$, thawed in cold water, sonicated for $3 \mathrm{~min}$ (Ultrasonic Processor; Heat Systems Ultrasonics), centrifuged and the supernatant (crude extract) removed and retained. The pellets were resuspended in the above buffer and retained as a suspension of insoluble material. An aliquot of amylose resin (New England Biolabs) was washed with the above buffer and mixed with an equal volume of crude extract. After incubating on ice for $15 \mathrm{~min}$, the resin was washed with the above buffer and resuspended in SDS-PAGE buffer.

Large-scale affinity purification of the fusion protein. Cultures of $E$. coli XL1-Blue containing the fusion plasmid were grown at $37^{\circ} \mathrm{C}$ to an $\mathrm{OD}_{600} \sim 0.5$. IPTG was added and incubation was continued at $22{ }^{\circ} \mathrm{C}$ for $4 \mathrm{~h}$. Fusion protein was purified using an amylose resin column. The diluted extract containing the fusion protein, stored on ice, was added to the column and then the column washed free of all protein other than the specifically bound MBP fusion protein. The fusion protein was eluted with column buffer containing $10 \mathrm{mM}$ maltose.

\section{RESULTS}

\section{Cloning of a haemolytic determinant from $R$. salmoninarum}

Screening of the pBR328 HindIII gene bank in E. coli DH1 resulted in the identification of a single clone, designated $\mathrm{H} 3$, which possessed a haemolytic phenotype. Clone $\mathrm{H} 3$ was found to contain plasmid DNA with a single $3.1 \mathrm{~kb}$ HindIII insert. The recombinant plasmid was designated pTHG1. Fig. 1 shows a restriction map of this plasmid. In an attempt to increase the yield of recombinant protein the $3.1 \mathrm{~kb}$ HindIII fragment was also subcloned in the plasmid vector pUC18 but the phenotype proved to be too unstable for any further meaningful manipulation. The haemolytic activity of clone $\mathrm{H} 3$ was observed from $6{ }^{\circ} \mathrm{C}$ to $37^{\circ} \mathrm{C}$ for erythrocytes from all species except rabbit, although only weak haemolysis was recorded against sheep erythrocytes. It was also observed that clones grown at $37^{\circ} \mathrm{C}$ were unstable and rapidly lost their haemolytic phenotype and consequently clones were routinely cultured at $22^{\circ} \mathrm{C}$. Clone $\mathrm{H} 3$ displayed no evidence of degradation of either casein, gelatin or $L-\alpha-$ phosphatidylcholine when compared with identically treated controls. E. coli strains Y1089 and Y1090, both of which possess mutations preventing the production of the Lon protease, were transformed with either PTHG1 or pBR328; stable clones were isolated at $22{ }^{\circ} \mathrm{C}$ and assayed for haemolytic activity as described above. The absence of the Lon protease did not affect the haemolytic phenotype encoded by PTHG1.

\section{Detection and identification of the haemolytic product encoded by PTHG1}

Cells and extracellular products harvested from clone $\mathrm{H} 3$ were resuspended in SDS-PAGE buffer and electrophoresed by SDS-PAGE. Gels were either stained for protein or transferred to nitrocellulose. Compared to control E. coli DH1 containing pBR328 alone, no additional proteins could be detected on either SDSPAGE gels or Western blots probed with rabbit antisera raised against $R$. salmoninarum ATCC 33209 whole cells, ECPs or cell walls. In addition, no haemolytic activity was associated with cell extracts or ECPs of clone H3. In order to simplify the identification of the haemolytic protein encoded by pTHG1, the plasmid was cleaved with either SalI alone or SalI and PvuII and then religated. Clones containing a SalI deletion of pTHG1 (designated pTHG101) were confirmed for sensitivity to tetracycline and were found to be haemolytic when compared with control E. coli DH1 containing pBR328. In contrast, clones containing both the SalI and PvuII deletions of pTHG1 (designated pTHG201) which were confirmed as sensitive to chloramphenicol were non-haemolytic using the same assay. Minicell analysis of the products encoded by each of the plasmid derivatives was performed in order to identify the haemolytic component. The autoradiograph of minicells which had been separated by SDSPAGE and transferred onto nitrocellulose showed only plasmid-encoded proteins including those conferring antibiotic resistance (Fig. 2). Compared to minicells containing pBR328 alone, minicells containing pTHG1 possessed at least four additional proteins of molecular masses 65, 46, 43 and $36 \mathrm{kDa}$. Minicells containing pTHG101 possessed only the $65 \mathrm{kDa}$ protein indicating that the $46 \mathrm{kDa}$ molecule was transcribed from the SalI end of the $3.1 \mathrm{~kb}$ HindIII DNA insert in pTHG1. Minicells containing pTHG 201 produced a $49 \mathrm{kDa}$ protein. On the basis of these results it was decided that haemolytic activity was conferred by the $65 \mathrm{kDa}$ protein and that the gene encoding this protein was located at the PvuII end of the $3.1 \mathrm{~kb}$ HindIII DNA insert. pTHG201 contained at most $1.3 \mathrm{kbp}$ of insert DNA which would be available for transcription, which would be insufficient for the translation of a $49 \mathrm{kDa}$ truncated protein. The $49 \mathrm{kDa}$ protein encoded by PTHG201 probably represented a serendipitous in-frame fusion of the remainder of the gene encoding the $65 \mathrm{kDa}$ protein with the remainder of the $\operatorname{cam}^{\mathrm{r}}$ gene and under the control of the cam $^{\mathrm{r}}$ promoter. The PvuII site of the cam $^{\mathrm{r}}$ gene is located $114 \mathrm{bp}$ downstream of the initiation codon. This would be sufficient to code for 38 amino acids of about $4 \mathrm{kDa}$ molecular weight with the additional $45 \mathrm{kDa}$ being encoded by insert DNA. Sequencing of the R. salmoninarum DNA substantiated these initial findings.

\section{The cloned $3.1 \mathrm{~kb}$ HindIII fragment is present in different isolates of $R$. salmoninarum}

Southern blot hybridization was carried out by digesting to completion with HindIII, chromosomal DNA from a number of isolates of $R$. salmoninarum including the type strain (ATCC 33209) as well as strains of $A$. salmonicida 
2

4

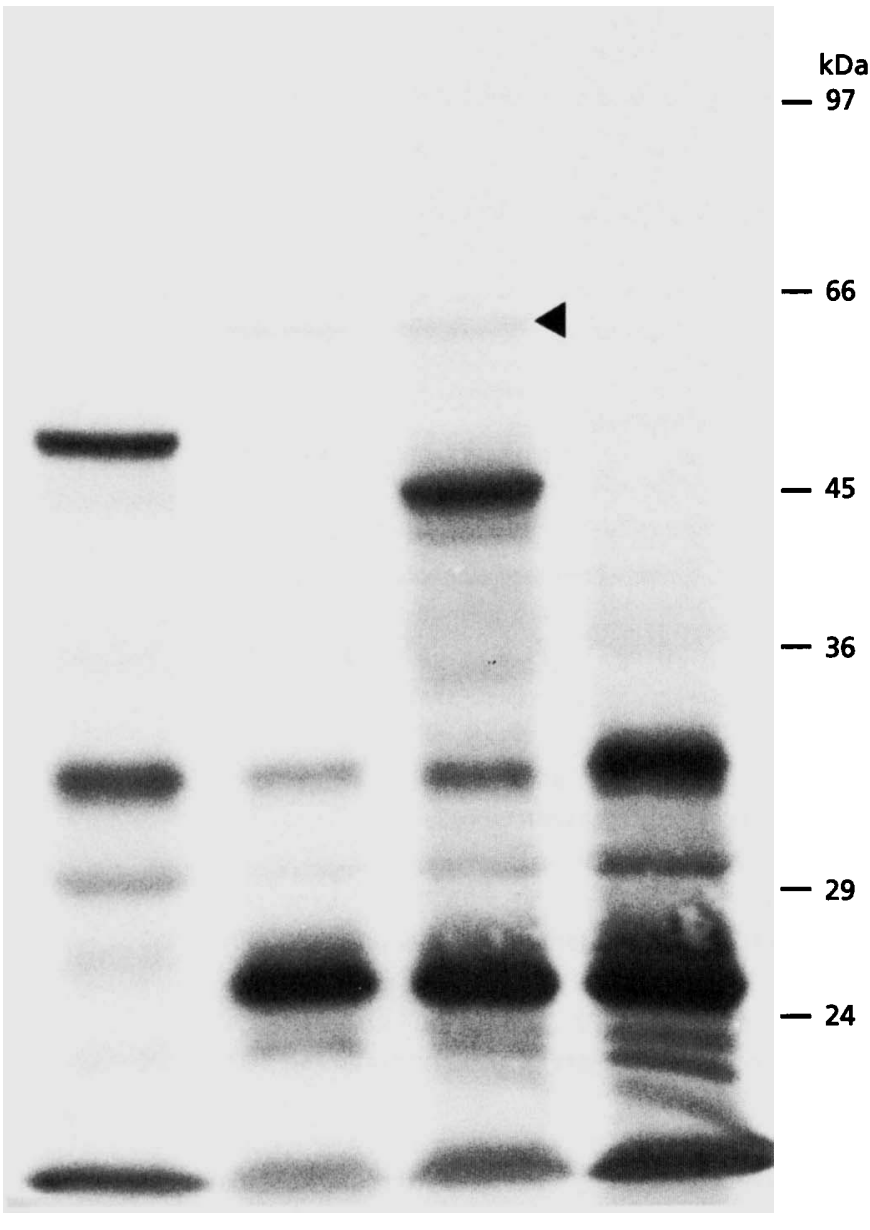

Fig. 2. Analysis of minicells containing either pBR328, pTHG1, pTHG101 or pTHG201. Approximately $50 \mu \mathrm{g}$ protein from each sample was separated by SDS-PAGE using a $10 \%$ polyacrylamide gel, transferred onto nitrocellulose and autoradiographed to reveal plasmid-encoded polypeptides labelled with $\left[{ }^{35} \mathrm{~S}\right]$ cysteine and $\left.{ }^{[35} \mathrm{S}\right]$ methionine. Tracks: 1 , pTHG201; 2, pTHG101; 3, pTHG1; 4, pBR328. The positions of molecular mass standards are indicated in $\mathrm{kDa}$. The arrow indicates the position of the $65 \mathrm{kDa}$ protein associated with haemolytic activity. Antibiotic resistance proteins are present at approximately $26 \mathrm{kDa}$ (chloramphenicol acetyltransferase), 29 and $32 \mathrm{kDa}$ ( $\beta$ lactamase) and $36 \mathrm{kDa}$ (tetracycline resistance).

(CM30) and $Y$. ruckeri (12/6), two other major fish pathogens. The cleaved DNA samples were separated by agarose gel electrophoresis, transferred to nitrocellulose and probed with $\mathrm{p}$ THG1 which had been random primed and non-radioactively labelled. A $3 \cdot 1 \mathrm{~kb}$ fragment corresponding to the $3.1 \mathrm{~kb}$ HindIII cloned insert was detected in chromosomal DNA from all isolates of $R$. salmoninarum but not $A$. salmonicida or $Y$. ruckeri (Fig. 3).

\section{Sequence of the gene encoding the haemolytic determinant}

Plasmid pTHG1 includes a 3.1 kb R. salmoninarum MT444 chromosomal DNA insert which contains the structural gene that encodes a haemolytic product. This $3.1 \mathrm{~kb}$

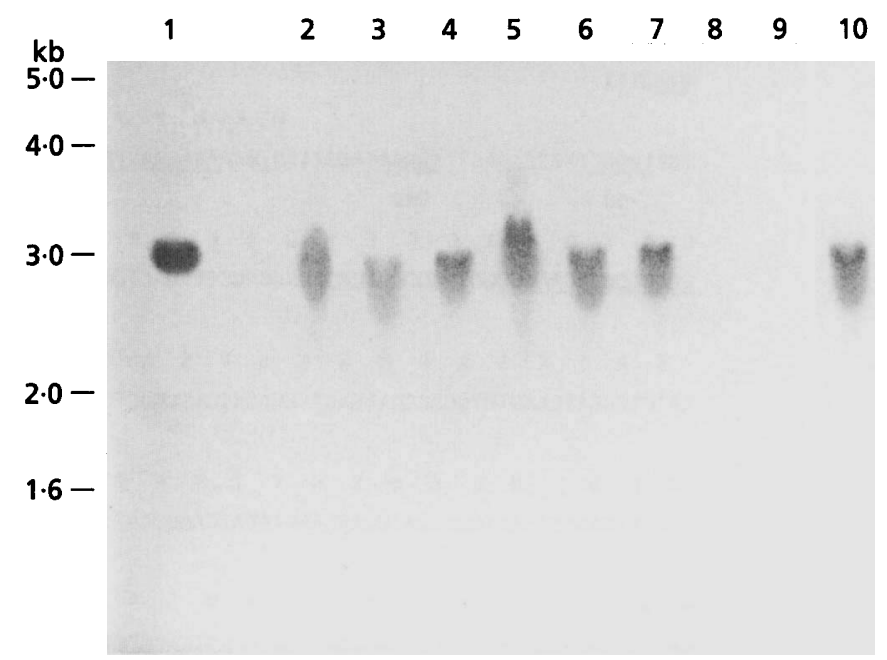

Fig. 3. Southern blot of $R$. salmoninarum, A. salmonicida and $Y$. ruckeri DNA $(5 \mu \mathrm{g})$ digested with HindIII. The DNA was probed with a digoxigenin-labelled $3.1 \mathrm{~kb}$ HindIII fragment of $R$. salmoninarum DNA. Lanes: $1,0.05 \mu \mathrm{g}$ probe; $2, \quad R$. salmoninarum strain ATCC 33209; $3, R$. salmoninarum isolate MT414; 4, $R$. salmoninarum isolate MT417; $5, R$. salmoninarum isolate MT420; $6, R$. salmoninarum isolate MT444; $7, R$. salmoninarum isolate MT452; $8, A$. salmonicida strain CM30; 9 , $Y$. ruckeri strain $12 / 6 ; 10, R$. salmoninarum isolate MT425. The positions of DNA molecular size markers are indicated in $\mathrm{kb}$.

fragment was characterized by restriction enzyme analysis (Fig. 1) and subcloned into the plasmid vector pUC18 as a series of three contiguous fragments. The sequencing templates, which were designated pURS1, pURS2 and pURS3, constituted $1.87 \mathrm{~kb}$ of pTHG1 insert DNA. Haemolytic activity was not detected in E. coli XL1-Blue transformants containing either pURS1, pURS2 or pURS3. A complete restriction map of the DNA sequence showed that the predicted restriction sites matched the observed endonuclease cleavage pattern. The correct orientation of the contiguous DNA fragments which formed the sequencing templates was confirmed by digesting pTHG1 with HincII to release a 980 bp DNA fragment. The nucleotide sequence was found to contain a possible open reading frame (ORF) of $1647 \mathrm{bp}$ starting at nucleotide 132 and ending at nucleotide 1778 with a $\mathrm{G}+\mathrm{C}$ ratio of $55 \cdot 5 \%$. Following translation, this putative ORF would code for a polypeptide of 548 amino acid residues with a calculated molecular mass of $66757 \mathrm{Da}$ and a pI of 5.57 (Fig. 4). The ATG triplet encountered at base pair 132 is preceded by a putative ribosome-binding site (AGGAA) located seven nucleotides upstream from this site. Possible -10 and -35 promoter regions are indicated (Fig. 4). Confirmation of the computer predictions of promoter region, transcriptional start site and initiation codon awaits corroborating transcriptional data. There were four sequences of imperfect dyad symmetry which were found to extend from nucleotides 10 to 80,47 to 155,189 to 298 and 1793 to 1830 . The last sequence, which is underlined in Fig. 4, resembles a rho-independent termination sequence being rich in $\mathrm{C}$ and $\mathrm{G}$ and also $\mathrm{T}$ bases at one end (Platt, 1986). 
AAGCIICAAACATAGATIITTCACAGTCTITGAAAACCGCAATAGGAATATIGCGGTTTTAATTATGTGGAAATCCTGIICAGIAATCAAAGATGTTIAC 100 HindIII TGA TAGCTITCTCTAACTIAGGAATAGGTITATGAAAAAGTACTACGCCGTAACTGGCATAGCTTTGGCTGTTGGCATGCTGTGTACAACGCAGCTCGCG 200 $-10+1$ RBS

G A T Q A A O P S V G S L O S S N V V T E F S A Q G N V E Q A I GGCGCCACTCAAGCCGCTGACCCCTCGGTGGGCAGCCTTGACTCGTCTAACGTCGTTACCGAGTTCTCCGCGCAMGGAATGTAGAGCAGATCACTTTCA 300

S A I K S A P M S S A R S A Q T S A I I P G L K N L F V S A P G S 90 AATCTGCCATCAAGTCTGCGCCGATGAGTTCGGCACGATCGGCTCAGACTAGCGCCATAATCCCCGGCCTTAAGAACTTGTTIGTGAGCGCGCCAGGTAG 400

D F S L N D S S N N Y I K R F T Q N I A G I P V L G S S I I T CGATTICAGCCTGAATGATTCATCGACAACTACATCAAGCGgTTCACGCAGAaCATCGCAGGCATCCCGGTGCTGGGCTCGTCAATTACTGAGGTCCTT 500

D G O G A $V$ T GATGGTCAGGGCGCTGTTACCTCGGCAATTGGTGCAGTCACCTCTGCTACTAAGGGTGCTTTCCCGGCTGATCTGCCGCAGGCCAAGCAGCAGCCCTGGC 600

R Q P R S P Q L A K T P A A I S L V D O K A I W F D A V L I G K G 190 ITCGGCAACCAAGATCGCCTCAGCTGGCAAAGACGCCAGCCGCGATCTCGCTTGITGACCAGAAAGCAATCTGGTICGACGCCGITCTTATCGGCAAGGG 700 Puill Hincll

A T G S V A V P A Y Q F S F T T G F A E S R V L T V A A N D $G$ A I AGCTACAGGCTCCGTTGCAGTCCCGGCGTACCAGTTCAGCTICACCACTGGATICGCAGAATCGCGgGTGCTCACGGTAGCTGCCAACGACGGCGCTATC 800

L N D R T D R K D I N R V V C D A N S TTGAATGACCGCACCGATCGCAAGGACATCAACCGCGTGGTCTGCGATGCGAACTCGAAGGTCATCGATCTTGAAGCTAGTAATGCAGATGCTCTGTTGA 900

C G K T G A N AGTGTGGCAAGACTCAGGCCAATAAGCCGACGCGCATTGAaGGCCAAGCTGCATCGTCAGTGGCCGATGTGAACTCGGTTTACAACTTTCTGAATGACAC 1000

A S F Y G A N TKA N D L T A L I G N D E G D G L G KA M RA $V$ V 323 TGCGTCGTTITACGGTGCAAACACTAAGGCCAATGATCTGACCGCACTTATTGGCAACGATGAAGGCGACGGTTTGGGCAAGGCAATGCGTGCCGTGGTC 1100

R I C V T D S Q N G E Q C P F A N A F N Y N G Q N

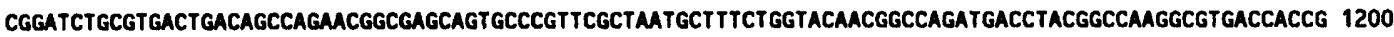

D I T G H E L T H G V T E K T N G L V Y A N E S G A I N E S M S D 390

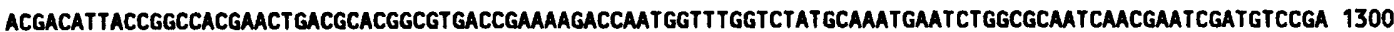

V F G E F I D L S N G S S D D T A A N R H A I G E G S S L G V I R 423 TGTATTCGGCGAGTTCATCGACTTGAGCAACGGCAGCTCGGATGACACTGCAGCTAACCGCTGGGCAATCGGCGAAGGCAGCAGCCTTGGTGTGATCCGG 1400 PstI

S M K D P G K Y Y G E P A I Y K G S N W K P

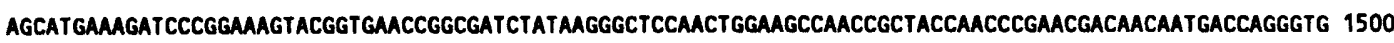

V H S N S G V G N K L A F L I T D G O GAGTTCACTCCAACAGCGGTGTGGGCAACAAGCTCGCATTCTTGATCACTGACGGCCAGACTTTCAACGGCCAGACCGTGACCGGAATTGGCATtGCTAA 1600

A A Q L Y H A A Q R Q L T A N A T Y S S L G K A L N S A C S A N V 523 GGCCGCTCAGCTITACTGGGCCGCACAGCGACAGITGACCGCAAATGCGACTTACTCGAGCTTGGGTAAGGCTTTGAACTCTGCTTGCAGTGCAAACGTT 1700 HineI I

S N N V A G T T A A N C T O V A N A I K A V G I K *

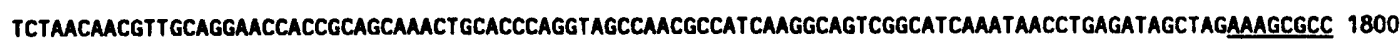
GGTITTCTCGCGAGAGGCAACCGGCGCTTTGCTITTAGATCGCTIAGCGAGTGCTTTCTATGGCCTGCAG 1870

Fig. 4. For legend see opposite page. 


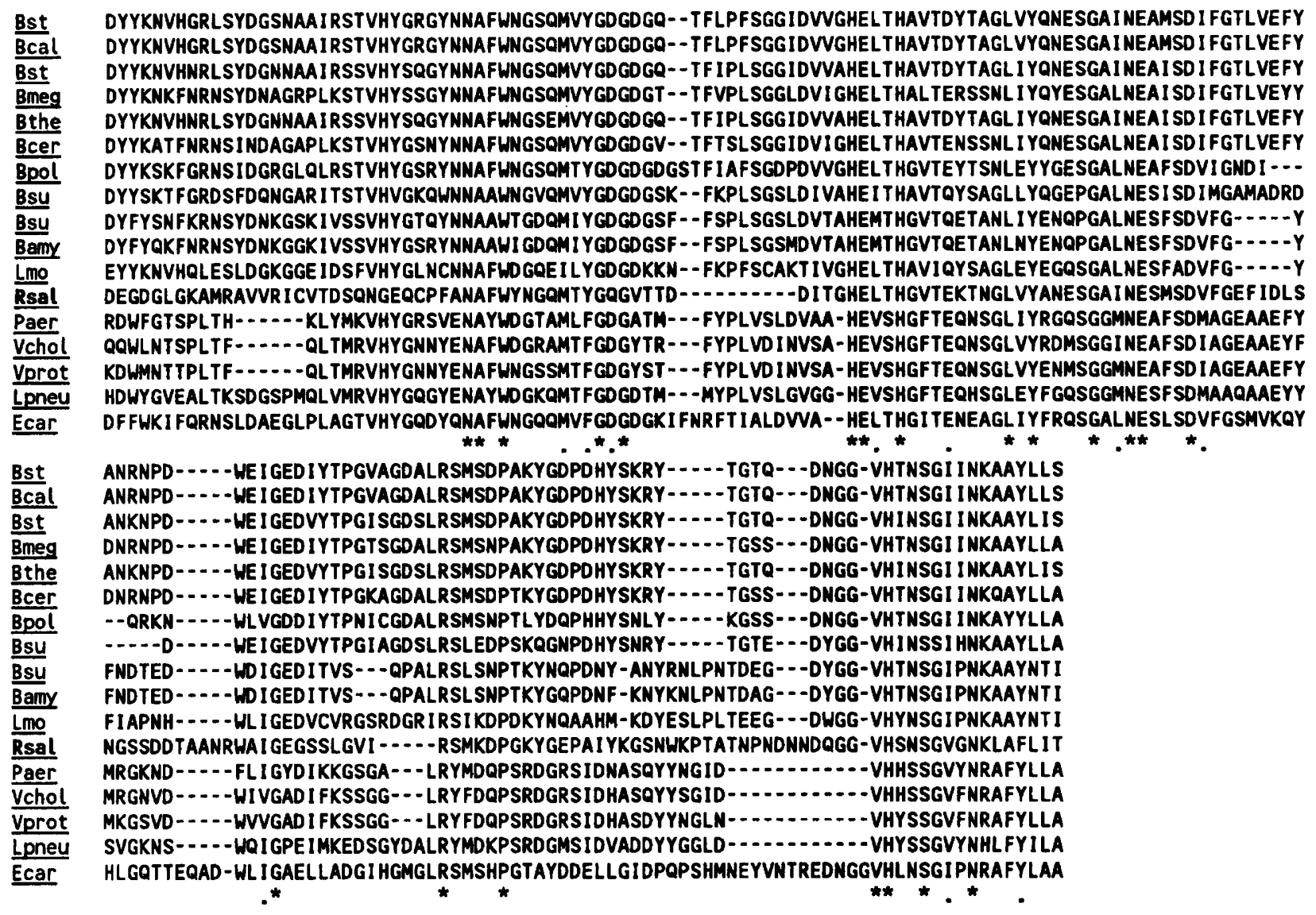

Fig. 5. Amino acid sequence alignment of metalloproteases of Bacillus, Erwinia, Legionella, Listeria, Pseudomonas and Vibrio from the PIR database and Renibacterium haemolysin showing the highly conserved residues which form the catalytic centre of the proteins. *, Identical residues;, conservative amino acid substitutions. Rsal, $R$. salmoninarum; Bst, B. stearothermophilus; Bcal, B. caldolyticus; Bmeg, B. megaterium; Bthe, B. thermoproteolyticus; Bcer, B. cereus; Bpol, B. polymyxa; Bsu, B. subtilis; Bamy, B. amyloliquefaciens; Lmo, L. monocytogenes; Paer, P. aeruginosa; Vchol, V. cholerae; Vprot, V. proteolyticus; Lpneu, L. pneumophila; Ecar, E. carotova.

A polypeptide identity search of the PIR database using the PROSCAN option of the DNAStar program revealed that the deduced protein sequence possessed strong similarities to a range of secreted bacterial zinc-metalloproteases, which are sometimes known as neutral proteases. All of these enzymes are members of a diverse family of zinc metalloendopeptidases which are recognized by a unique signature, His-Glu-X-X-His, and include representatives from both prokaryote and eukaryote groups (Jongeneel et al., 1989; Auld \& Vallee, 1990). The similarities were substantial and highly conserved with respect to the residues forming the catalytic centre of these enzymes (Fig. 5). Furthermore, computer predictions of the secondary structure of the $R$. salmoninarum protein indicated that, as for other zincmetalloproteases, the putative catalytic sites occurred in helical regions of the molecule. In the absence of conclusive biochemical information the gene encoding this polypeptide has been designated $b l y$, denoting haemolysin of $R$. salmoninarum. The first 84 nucleotides of bly encode a 28 amino acid peptide that bears all the features of a prokaryotic signal peptide sequence (Simonen \& Palva, 1993). The $\mathrm{N}$-terminus contained two positively charged lysine residues immediately following the methionine initiator. There was a hydrophobic core of 16 residues followed by more polar amino acids. The proposed processing site is between alanine residues 28 and 29 , which are predicted to be surface-exposed in a flexible, turn region.

\section{Construction and purification of a MBP-Hly fusion protein}

From the restriction map available of the bly gene a restriction site close to the $\mathrm{N}$-terminus was identified as suitable for the construction of an in-frame gene fusion

Fig. 4. Nucleotide sequence and deduced amino acid sequence of the hly gene from $R$. salmoninarum. The putative promoter region and transcriptional start site are indicated as $-35,-10$ and +1 , respectively. The putative ribosomebinding site (RBS), signal peptide and transcription termination sequence are underlined. 
(a)

HindIII Pvull Pstl Pstl Sall $\underbrace{\text { Ehel }}_{\text {Ehel }}$

(b)

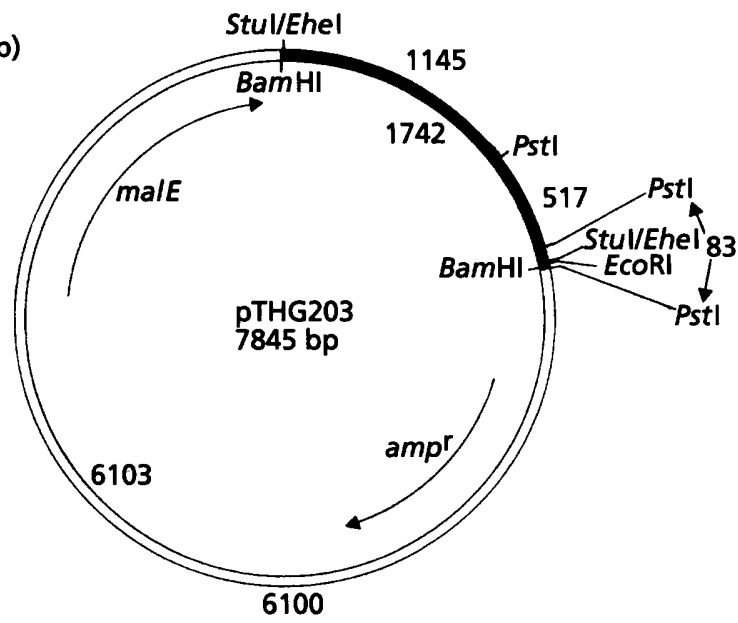

Fig. 6. (a) Cloning strategy for the construction of a fusion of gene malE with gene hly and (b) physical map deduced for pTHG203. Numbers represent bp between neighbouring restriction sites. ampr, gene encoding ampicillin resistance; malE, gene encoding MBP.

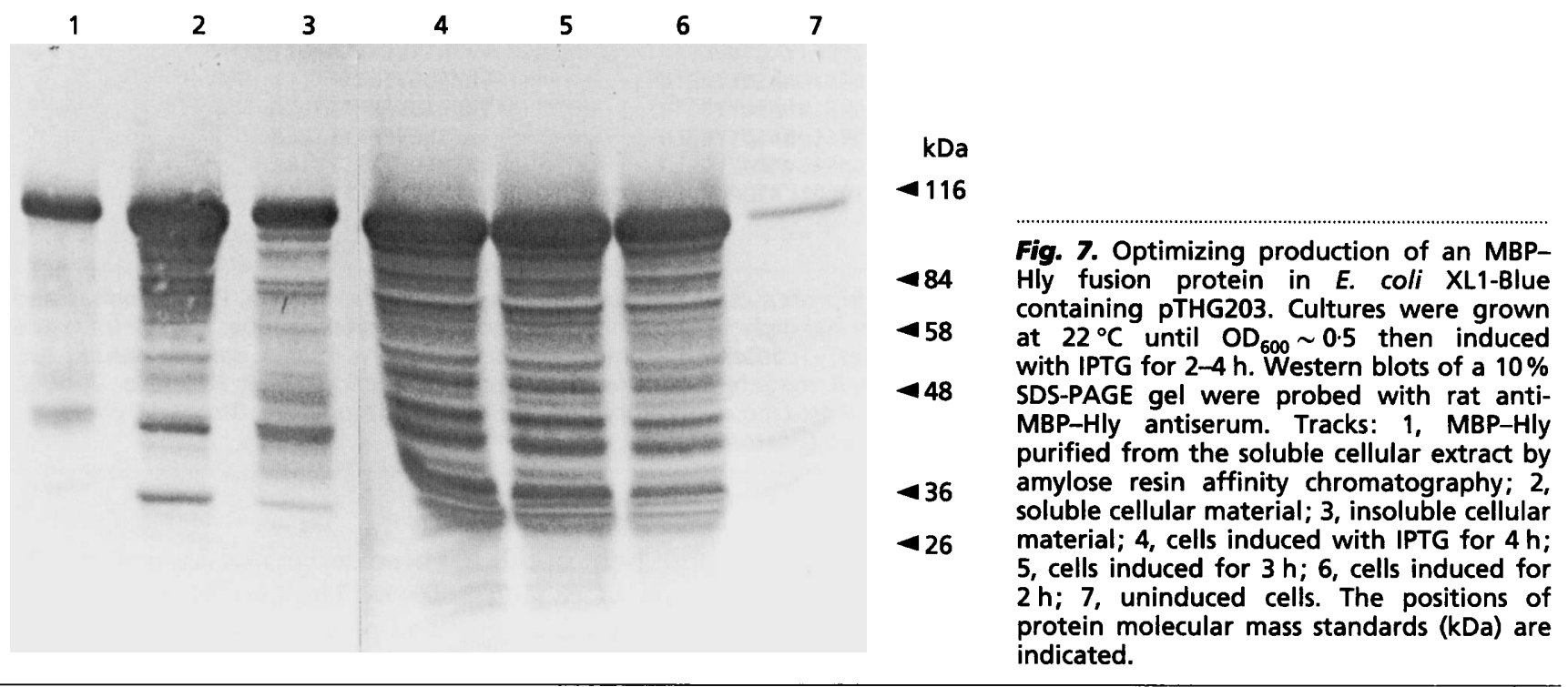

with the malE gene encoding MBP. A blunt-ended EheI site located at nucleotide 203 (Fig. 6) provided an in-frame fusion when ligated to the StuI site of the pMAL polylinker. This manipulation was expected to yield 524 amino acids of the $R$. salmoninarum protein with a molecular mass of $63842 \mathrm{Da}$ fused to MBP. A recombinant plasmid, designated pTHG203 (Fig. 6), containing an in-frame fusion between bly and malE was constructed and expressed in E. coli XL1-Blue. E. coli clones producing the fusion protein (MBP-Hly) were identified by Western blotting using rabbit anti-MBP antiserum. MBP-Hly was produced cytoplasmically in $E$. coli using PMAL-c only, because of the difficulty in isolating clones expressing the fusion in the pMAL-p vector. Hly was fused to MBP starting from Ala-25, which is four amino acids upstream of the predicted signal peptide cleavage point at Ala-28. Construction of recom- binant plasmid pTHG203 allowed the production of a fusion protein composed of the entire MBP molecule (molecular mass $42.7 \mathrm{kDa}$ ) fused at the $\mathrm{C}$-terminus, with a short factor $\mathrm{Xa}$ cleavage site, to 524 amino acids (molecular mass $63842 \mathrm{Da}$ ) derived from $R$. salmoninarum haemolysin (Hly). The small-scale pilot experiment showed after $2-4 \mathrm{~h}$ induction that MBP-Hly was produced at a high level and mainly in a soluble form (Fig. 7). Because considerable breakdown and instability was observed at $37^{\circ} \mathrm{C}$, IPTG induction was carried out at $22^{\circ} \mathrm{C}$. Inducing at $22^{\circ} \mathrm{C}$ in conjunction with a second sonication of the insoluble cell material greatly improved the stability and yield of MBP-Hly. The MBP-Hly protein was purified from the cytoplasm of $E$. coli containing recombinant plasmid pTHG203 by using a one-step affinity chromatography procedure as described in Methods. Purified MBP-Hly migrated as a single band 
on SDS-PAGE with an apparent molecular mass of $105 \mathrm{kDa}$, which was similar to the predicted molecular mass of $106542 \mathrm{Da}$. Protein concentrations were estimated by the method of Bradford (1976) and yields of $50 \mu \mathrm{g}$ (ml culture) ${ }^{-1}$ were obtained.

\section{Expression of $h l y$ is modulated by the availability of iron}

Western blots of MBP-Hly which were probed with antisera from rats immunized with purified MBP-Hly showed good recognition of the fusion protein (Fig. 7). Cell extracts or ECPs were obtained from seven isolates of $R$. salmoninarum which had been cultured under either iron-restricted or iron-sufficient conditions, separated by SDS-PAGE and blotted onto nitrocellulose. Western blots of sonicated $R$. salmoninarum cell extracts derived from iron-sufficient cultures which were probed with rat anti-MBP-Hly revealed the presence of strongly immunoreactive bands of approximately 70 and $25 \mathrm{kDa}$ with a weakly stained $48 \mathrm{kDa}$ band in all isolates (Fig. 8a). However, these bands were barely discernible on Western blots of cell extracts from iron-restricted cultures (Fig. $8 \mathrm{~b})$. No bands were detected by the MBP-Hly antiserum on Western blots of ECPs from either iron-restricted or iron-sufficient cultures.

\section{DISCUSSION}

This study has described a novel haemolysin from $R$. salmoninarum. Gene bly has been found to be present in each of the seven isolates of $R$. salmoninarum so far examined and the nucleotide content was $55.5 \% \mathrm{G}+\mathrm{C}$, consistent with the overall $55.5 \% \mathrm{G}+\mathrm{C}$ of the $R$. salmoninarum chromosome (Banner et al., 1991). Gene bly encodes a product which confers a haemolytic phenotype on $E$. coli. The active component, as identified by minicell analysis, possessed an apparent molecular mass of $65 \mathrm{kDa}$ and was active against erythrocytes from a number of animal species, including rainbow trout but not rabbit, from $6{ }^{\circ} \mathrm{C}$ to $37^{\circ} \mathrm{C}$. These features are reminiscent of those of a membrane-active toxin. The results of other researchers investigating the immunological and enzymic properties of ECPs or whole cells from in vitro cultures of $R$. salmoninarum have failed to identify any haemolytic or cytotoxic components although proteolytic activities have been demonstrated (Bandín et al., 1991; Griffiths \& Lynch, 1991; Rockey et al., 1991). The possible contribution of an unidentified toxic component to the pathology of the disease has been suggested (Bruno \& Munro, 1986; Turaga et al., 1987). It is notable that Bruno \& Munro (1986) provide the only report of $\beta$-haemolysis by $R$. salmoninarum isolates cultured in vitro and this activity was recorded against rabbit erythrocytes. In addition, Bruno \& Munro (1986) found that $\beta$-haemolysis declined following routine subculture of $R$. salmoninarum with an accompanying decline in the virulence of the organism. Evenden et al. (1990) reported the cloning of a gene from $R$. salmoninarum encoding a product which was capable of lysing rabbit erythrocytes. The product of gene bly, on the other hand, was not found to be active against

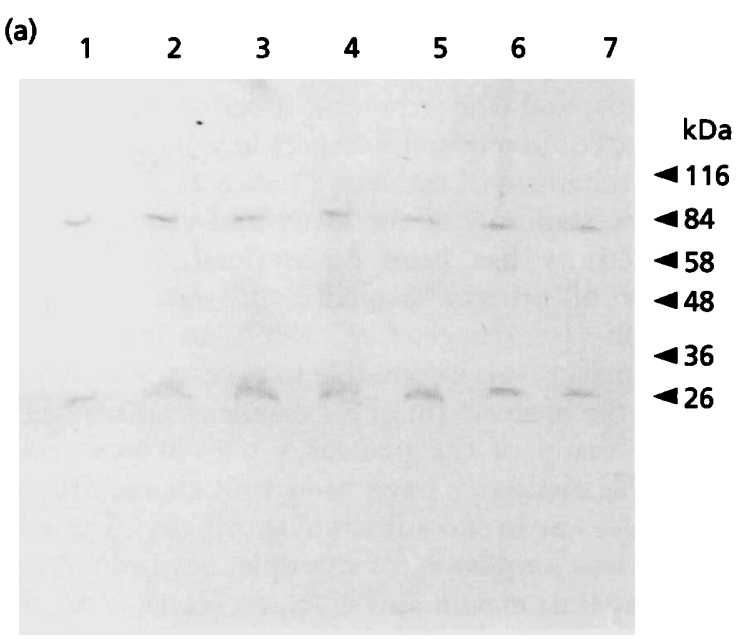

(b)

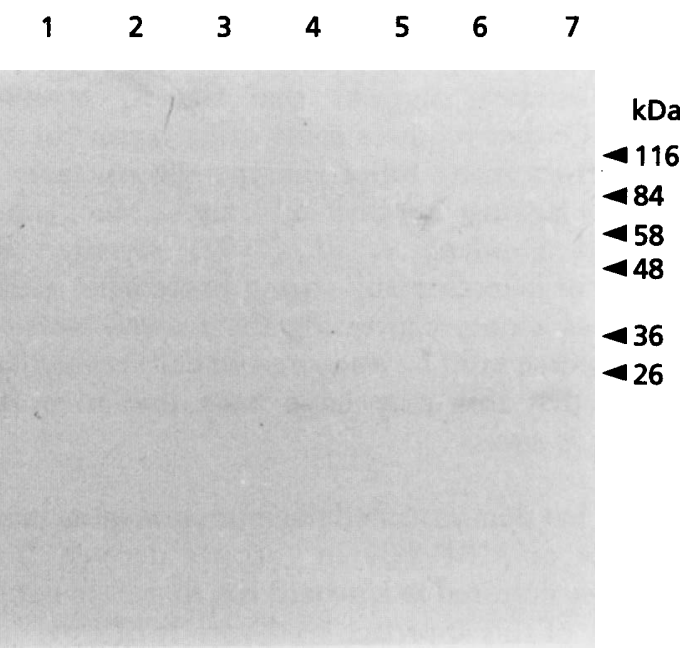

Fig. 8. The detection of epitopes of MBP-Hly in cell extracts of seven $R$. salmoninarum isolates which had been cultured in either (a) MHCB or (b) MHCB supplemented with $200 \mu \mathrm{M}$ EDDHA. Preparations were separated by SDS-PAGE using a $10-15 \%$ gradient gel, transferred onto nitrocellulose and then probed with a rat antiserum raised against MBP-Hly. All tracks contained an equivalent amount of protein $(2 \mu \mathrm{g})$. Tracks: 1 , isolate $910019 ; 2$, isolate MT452; 3 , isolate MT425; 4, isolate MT420; 5, isolate MT417; 6, isolate MT414; 7, strain ATCC 33209. The positions of protein molecular mass standards are marked (kDa).

rabbit erythrocytes, and furthermore did not degrade either casein or gelatin. The instability of clones in which the gene is expressed at $37^{\circ} \mathrm{C}$ or when inserted into the pUC18 vector, and the difficulty in maintaining cultures of $E$. coli which contained pTHG1, either stored at $-20^{\circ} \mathrm{C}$ or at $4{ }^{\circ} \mathrm{C}$, provide an indication of the toxicity of the protein to $E$. coli cells. Because of the difficulties experienced with high level expression of the protein and lack of a means of detecting the protein in cell extracts or ECPs of either E. coli clones or R. salmoninarum cultures, further biochemical characterization was considered to be impossible at this stage.

Zinc-dependent endopeptidases form a heterogeneous family, with widely differing specificities and sensitivity to 
inhibitors (Jongeneel et al., 1989). It has been suggested that variation in the spacer regions between the catalytic zinc ligands and the residues forming the substratebinding site could reflect differences in substrate specificity and the mechanism of catalysis (Vallee \& Auld, 1989). A better understanding of the structural requirements for enzyme activity has been constrained by the limited availability of protein sequence and tertiary structure information (Jongeneel et al., 1989). In the absence of such information it is impossible to predict what degree of specificity the haemolysin of $R$. salmoninarum may exhibit. However, many of the proteases with which it shares considerable similarity have been well characterized and found to possess broad substrate specificity. The elastase of Pseudomonas aeruginosa, for example, has been shown to be active against elastin and collagen (Heck et al., 1986), human IgA and IgG (Döring et al., 1981) and several complement components (Hong \& Ghebrehiwet, 1992). The failure to detect proteolytic activity against casein and gelatin substrates suggests that the $R$. salmoninarum haemolysin either requires some other factor for activity or differs from many other zinc-metalloproteases and is only active against specific substrates. Mengaud et al. (1991) and Domann et al. (1991) reported similar difficulties in detecting any strong proteolytic activity in either $E$. coli clones expressing the Listeria monocytogenes metalloprotease or in L. monocytogenes culture medium and suggested that this may have been due to a lack of processing in vitro.

This study has demonstrated the immunological detection of epitopes of MBP-Hly in extracts derived from $R$. salmoninarum cultured in vitro and has therefore confirmed the validity of this approach to the study of a particularly difficult pathogen. It should be noted that $R$. salmoninarum does not utilize starch or maltose (Goodfellow et al., 1985) and Western blots of $R$. salmoninarum cultures which were probed with rabbit anti-MBP antiserum showed no evidence for the recognition of cross-reactive epitopes. The availability of rat anti-MBP-Hly antiserum will therefore prove useful in future research. The immunological detection of epitopes of MBP-Hly revealed a number of bands in the cell extracts of all seven isolates of R. salmoninarum which were examined. No components were detected in the ECPs. It seems likely that the various bands represent breakdown products of the $67 \mathrm{kDa} H \mathrm{Hly}$ protein. However, the possibility exists that they represent cross-reacting epitopes on other proteins. Many zincmetalloproteases are secreted as preproenzymes and the mature protease is produced following cleavage of the propeptide (Simonen \& Palva, 1993). In addition, these bands were almost undetectable under iron-restricted conditions suggesting that the production of Hly by $R$. salmoninarum is greatly reduced when iron is no longer freely available. Whether the regulation of the production of Hly occurs at the transcriptional level or as a consequence of post-transcriptional factors such as the induction or suppression of other genes with a regulatory function is unknown. The precise contribution of metal ions such as $\mathrm{Fe}^{3+}, \mathrm{Fe}^{2+}, \mathrm{Zn}^{2+}$ and $\mathrm{Ca}^{2+}$ to the regulation of $R$. salmoninarum growth and the production of specific components, such as Hly, awaits the development of a defined growth medium and better elucidation of the metal ion requirements of $R$. salmoninarum. The lack of immunologically detectable $\mathrm{Hly}$ in the ECPs of $R$. salmoninarum cultures suggests that Hly was not secreted under the culture conditions employed in this study. However, the presence of a signal peptide at the $\mathrm{N}$ terminus of Hly which bears a strong resemblance to other prokaryotic signal sequences suggests that this protease would be expected to be exported across the $R$. salmoninarum cell wall. It may be that Hly remains attached to or associated with the cell wall and thus does not form a readily detectable part of the ECPs.

\section{ACKNOWLEDGEMENTS}

We thank the Scottish Salmon Growers Association for funding, SOAFD Marine Laboratory, Aberdeen, Scotland, for bacterial isolates, helpful advice and assistance, and Drs C. J. Rodgers, A. B. Wrathmell and P. J. Glynn for assistance.

\section{REFERENCES}

Auld, D. S. \& Vallee, B. L. (1990). Zinc coordination, function and structure of zinc enzymes and other proteins. Biochemistry 29, 5647-5659.

Bandín, I., Santos, Y., Bruno, D. W., Raynard, R. S., Toranzo, A. E. \& Barja, J. L. (1991). Lack of biological activities in the extracellular products of Renibacterium salmoninarum. Can J Fish Aquat Sci 48, 421-425.

Banner, C. R., Rohovec, J. S. \& Fryer, J. L. (1991). A new value for mol percent guanine + cytosine of DNA for the salmonid fish pathogen Renibacterium salmoninarum. FEMS Microbiol Lett 79, $57-60$.

Bradford, M. (1976). A rapid and sensitive method for the quantitation of microgram quantities of protein utilizing the principle of protein-dye binding. Anal Biocbem 72, 248-254.

Bruno, D. W. (1988). The relationship between auto-agglutination, cell surface hydrophobicity and virulence of the fish pathogen Renibacterium salmoninarum. FEMS Microbiol Lett 51, 135-140.

Bruno, D.W. (1990). Presence of saline extractable protein associated with virulent strains of the fish pathogen Renibacterium salmoninarum. Bull Eur Assoc Fish Pathol 10, 8-10.

Bruno, D. W. \& Munro, A. L. S. (1986). Haematological assessment of rainbow trout, Salmo gairdneri Richardson, and Atlantic salmon, Salmo salar L, infected with Renibacterium salmoninarum. J Fish Dis $\mathbf{9}$, 195-204.

Daly, J. G. \& Stevenson, R. M. W. (1990). Characterization of the Renibacterium salmoninarum haemagglutinin. J Gen Microbiol 136, 949-953.

Domann, E., Leimeister-Wachter, M., Goebel, W. \& Chakraborty, T. (1991). Molecular cloning, sequencing and identification of a metalloprotease gene from Listeria monocytogenes that is species specific and physically linked to the listeriolysin gene. Infect Immun 59, 65-72.

Dbring, G., Obernesser, H.-J. \& Botzenhart, K. (1981). Extracellular toxins of Pseudomonas aeruginosa II. Effect of two proteases on human immunoglobulins IgG, IgA and secretory IgA. Zentralbl Bakteriol Mikrobiol Hyg 1 Abt Orig A 249, 89-98.

Dougan, G. \& Kehoe, M. (1984). The minicell system as a method for studying expression from plasmid DNA. Methods Microbiol 17, 233-258.

Evelyn, T. P. T. (1993). Bacterial kidney disease - BKD. In Bacterial 
Diseases of Fish, pp. 177-195. Edited by V. Inglis, R. J. Roberts \& N. R. Bromage. Oxford: Blackwell.

Evenden, A. J., Gilpin, M. L. \& Munn, C. B. (1990). The cloning and expression of a gene encoding haemolytic activity from the fish pathogen R. salmoninarum. FEMS Microbiol Lett 71, 31-34.

Evenden, A. J., Grayson, T. H., Gilpin, M. L. \& Munn, C. B. (1993). Renibacterium salmoninarum and bacterial kidney disease-the unfinished jigsaw. Annu Rev Fish Dis 3, 87-104.

Finlay, B. B. \& Falkow, S. (1989). Common themes in microbial pathogenicity. Microbiol Rev 53, 210-230.

Getchell, R. G., Rohovec, J. S. \& Fryer, J. L. (1985). Comparison of Renibacterium salmoninarum isolates by antigenic analysis. Fish Pathol 20, 149-150.

Goodfellow, M., Embley, T. M. \& Austin, B. (1985). Numerical taxonomy and emended description of Renibacterium salmoninarum. $J$ Gen Microbiol 131, 2739-2752.

Grayson, T. H. (1993). Molecular cloning and characterization of potential vaccine antigens from Renibacterium salmoninarum. $\mathrm{PhD}$ thesis, University of Plymouth, UK.

Griffiths, S. G. \& Lynch, W. H. (1991). Instability of the major soluble antigen produced by Renibacterium salmoninarum. $J$ Fish Dis 14, 55-66.

Guan, C., Li, P., Riggs, P. D. \& Inouye, H. (1987). Vectors that facilitate the expression and purification of foreign peptides in Escherichia coli by fusion to maltose-binding protein. Gene 67, 21-30.

Heck, L. W., Morihara, K., McRae, W. B. \& Miller, E. J. (1986). Specific cleavage of human type III and IV collagens by $P_{\text {seudomonas }}$ aeruginosa elastase. Infect Immun 51, 115-118.

Hong, Y. \& Ghebrehiwet, B. (1992). Effect of Pseudomonas aeruginosa elastase and alkaline protease on serum complement and isolated components C1q and C33 . Clin Immunol Immunopathol 62, 133-138.

Jongeneel, C. V., Bouvier, J. \& Bairoch, A. (1989). A unique signature identifies a family of zinc-dependent metallopeptidases. FEBS Lett 242, 211-214.

Laemmli, U. K. (1970). Cleavage of structural proteins during the assembly of the head of bacteriophage T4. Nature 222, 680-685.

Maina, C. V., Riggs, P. D., Grandea, A. G., III, Slatko, B. E., Moran, L. S., Tagliamonte, J. A., McReynolds, L. A. \& Guan, C. (1988). A vector to express and purify foreign proteins in Escherichia coli by fusion to, and separation from, maltose-binding protein. Gene 74, 365-373.

Maniatis, T., Fritsch, E. F. \& Sambrook, J. (1982). Molecular Cloning: a Laboratory Manual. Cold Spring Harbor, NY: Cold Spring Harbor Laboratory.

Mengaud, J., Geoffroy, C. \& Cossart, P. (1991). Identification of a new operon involved in Listeria monocytogenes virulence: its first gene encodes a protein homologous to bacterial metalloproteases. Infect Immun 59, 1043-1049.

Platt, T. (1986). Transcription termination and regulation of gene expression. Annu Rev Biochem 55, 339-372.

Rockey, D. D., Turaga, P. S. D., Wiens, G. D., Cook, B. A. \& Kaattari, S. L. (1991). Serine proteinase of Renibacterium salmoninarum digests a major autologous extracellular and cellsurface protein. Can J Microbiol 37, 758-763.

Simonen, M. \& Palva, I. (1993). Protein secretion in Bacillus species. Microbiol Rev 57, 109-137.

Southern, E. M. (1975). Detection of specific sequences among DNA fragments separated by gel electrophoresis. $J$ Mol Biol 98, 503-517.

Towbin, H., Staehelin, T. \& Gordon, J. (1979). Electrophoretic transfer of proteins from polyacrylamide gels to nitrocellulose sheets : procedure and some applications. Proc Natl Acad Sci USA 76, 4350-4354.

Turaga, P., Wiens, G. \& Kaattari, S. (1987). Bacterial kidney disease: the potential role of soluble protein antigen(s). J Fish Biol Suppl $A$ 31, 191-194.

Vallee, B. L. \& Auld, D. S. (1989). Short and long spacer sequences and other structural features of zinc binding sites in zinc enzymes. FEBS Lett 257, 138-140.

Wiens, G. D. \& Kaattari, S. L. (1991). Monoclonal antibody characterization of a leukoagglutinin produced by Renibacterium salmoninarum. Infect Immun 59, 631-637.

Received 20 June 1994; revised 21 December 1994; accepted 22 February 1995. 